\title{
The Effect of Cooperative Learning Methods on Pre Service Elementary Mathematics Teachers' Academic Achievement and Retention in the Subject of Analytical Examination of the Circle
}

\section{Murat DIRLIKLí, Levent AKGÜN ${ }^{b^{*}}$}

${ }^{a}$ Siirt Üniversitesi, Eğitim Fakültesi, Matematik ve Fen Bilimleri Eğitimi Bölümü

${ }^{b}$ Atatürk Üniversitesi, Kazım Karabekir Eğitim Fakültesi, Matematik ve Fen Bilimleri Eğitimi Bölümü

\begin{tabular}{l}
\hline Article Info \\
\hline DOI: $10.14812 /$ cuefd. 346167 \\
\hline
\end{tabular}
\begin{abstract}
The aim of this study is to determine the effects of Student Teams Achievement Divisions (STAD) and Learning Together (LT) methods of cooperative learning model and the conventional methods on academic achievement and retention of the knowledge leraned in the subject of Analytic Examination of the Circle of candidates of primary school mathematics teaching. Quantitative research methods are used in and this study is designed according quasi-experimental to pre-test, post-test design with control group. The sampling of the study is formed by the 76 students in normal and evening education groups of 3rd grade in primary school mathematics teaching department at a state university. The achievement test formed by the researcher, module tests are used as data collection tools in the study. The study is held with 2 experimental and 1 control groups in totally three classes. STAD method is used in

\begin{tabular}{|c|c|}
\hline \multicolumn{2}{|c|}{$\begin{array}{l}\text { İşbirlikli Öğrenme Yöntemlerinin Çemberin Analitik İncelenmesi konusunda } \\
\text { İlköğretim Matematik Öğretmeni Adaylarının Akademik Başarılarına ve } \\
\text { Kalıcılık Düzeylerine Etkisi }\end{array}$} \\
\hline Makale Bilgisi & Öz \\
\hline DOI: 10.14812/cuefd. 346167 & $\begin{array}{l}\text { Bu çalışmanın amacı işbirlikli öğrenme yöntemlerinden Öğrenci Takımları Başarı Bölümleri } \\
\text { (ÖTBB) ve Birlikte Öğrenme (BÖ) ile geleneksel öğretim yönteminin Çemberin Analitik }\end{array}$ \\
\hline & $\begin{array}{l}\text { İncelenmesi konusunda ilköğretim matematik öğretmeni adaylarının akademik başarılarına, } \\
\text { edinilen bilgilerin kalıcılığına etkisini belirlemektir. Çalışmada nicel araştırma yöntemi } \\
\text { kullanılmıs, yarı-deneysel yapıda ön test-son test kontrol gruplu desene göre tasarlanmıştır. } \\
\text { Çalışmanın örneklemini bir devlet üniversitesinin ilköğretim matematik öğretmenliği bölümü } \\
\text { normal ve ikinci öğretim programının } 3 . \text { sınıfına kayıtlı } 76 \text { öğretmen adayı oluşturmaktadır. } \\
\text { Çalışmada veri toplama aracı olarak araştırmacı tarafından geliş̧irilen başarı testi ile modül } \\
\text { testler kullanılmıştır. Araştırma } 2 \text { deney } 1 \text { kontrol grubu olmak üzere } 3 \text { sınıfta } \\
\text { gerçekleştirilmiştir. Bu grupların birincisinde ÖTBB yöntemi, ikincisinde BÖ yöntemi, } \\
\text { üçüncüsünde ise geleneksel öğretim yöntemi kullanılmıştır. Verilerin analizi için tanımlayıcı }\end{array}$ \\
\hline $\begin{array}{l}\text { Anahtar Kelimeler: } \\
\text { İşbirlikli Öğrenme Yöntemleri, Öğrenci } \\
\text { Takımları Başarı Bölümleri Yöntemi, } \\
\text { Birlikte Öğrenme Yöntemi, Çemberin } \\
\text { Analitik İncelenmesi. }\end{array}$ & $\begin{array}{l}\text { istatistikler, tek yönlü varyans analizi (ANOVA), LSD çoklu karşılaştırma testi kullanıımıştır. } \\
\text { Sonuç olarak; ÖTBB ve BÖ yöntemlerinin geleneksel öğretim yöntemine göre öğrencilerin } \\
\text { akademik başarıları ve bilgilerin kalıcılığı üzerinde daha etkili olduğu görülmüşşür. Öğrencilerin } \\
\text { akademik başarıları üzerinde ÖTBB yönteminin, edinilen bilgilerin kalıclığında ise BÖ } \\
\text { yönteminin daha etkili olduğu sonucuna ulaşılmıştır. }\end{array}$ \\
\hline
\end{tabular}




\section{Introduction}

Education systems play the most active role in upbringing the human model required by the information age we live in. Accordingly, education systems try to improve themselves in order to provide students with skills to gain information and improve them, besides transferring existing knowledge to students. Students need to have rich and effective learning experiences in order to acquire these high-level mental process skills. These learning experiences, however, are available in active learning environments where students are encouraged scientific thinking and self-renewal, learners interact with one another, and the responsibility of the learning process is taken by themselves (Ozyurt, 2013). The creation of environments in which students can be actively involved in the learning process, however, is directly related to the selection of appropriate teaching methods and techniques. Thus, a teaching process based on consideration and investigation should be combined with expertly prepared teaching techniques and students should be tried to be activated in the classroom (Bonwel and Eison, 1991; as cited in Ozyurt, 2013).

Student-centered teaching methods are regarded and implemented in active learning. Active learning makes learning an operational process where students are actively involved and teachers control this process, rather than being person to 'present the information'. Active learning process has significant contributions to provide learners acquire advanced skills they may use in their life and engage in intellectual initiatives (Akpinar and Gezer, 2010).

The objectives of active learning are to free students from the passive status in the educational process and to create learning processes in which students are effective and actively participating (Caliskan, 2005).In active learning, students reach their own resources in research studies, learn the ways to access information from various sources, organize and present information they obtain, take responsibility and share in individual and group projects. They interact and collaborate for the production of common information (Akar, 2012;Savas, Obay \& Duru, 2008). Hence, learners take an active role in the learning and teaching environment. For this reason, researchers and educators want to develop and implement learning environments in which learners have an active role.

One of the learning approaches learners take an active role in the learning activities is the Cooperative Learning Model. Cooperative learning is a kind of group work composed of different methods, which aims to increase the learning capabilities of both group of friends and students themselves in small groups by common objectives. This learning method attracts a growing interest in many countries, particularly in the United States, around world (Ozyurt, 2013). This interest is indicated by the increasing number of studies conducted so far, the density of activities regarding training students in cooperative learning, the number of participants in these activities and the excessive number of publications on this subject (Timur, 2006).

Cooperative learning is used in mathematics, language education, social studies, science and many other subjects, starting from the second grade in primary to undergraduate degree (Gomleksiz, 1997).Ural (2007) cites Davidson (1985) that cooperative learning is regarded as an alternative method for the development of Mathematics teaching.

Geometry constitutes an important area of mathematics. Geometry information is widely and often used in many courses and problem solving. For these reasons, geometry teaching also constitutes an important part of Mathematics teaching. In order for the geometric thinking to be realized, it is essential to teach geometric concepts. For effective geometry teaching, it is vital and crucial that teachers should have skills to understand students, diagnose the level of their learners, and use communicative language appropriate to their level/s. The geometry success of students is closely and directly related to teacher's geometry knowledge capacity and ability to improve this capacity (Duru, 2010).

Because of the fact that "Faculties of Education" are the first settings where teachers began to step into the teaching profession, teachers should be provided a quality education in universities. Quality education preservice Math teachers receive and different methods they learn and use in university will also contribute to teaching analytic geometry course topics in an effective way, when they start teaching (Ozerdem, 2007).

From the very first time when the dominance of teamwork to individual work was noticed, the impact of cooperative learning on the academic success has been the subject of numerous studies up to the present. In the majority of these studies, cooperative learning method is compared to traditional learning method and cooperative learning method was determined to be more effective than traditional teaching method, as expected (Avsar and Alkis, 2007; Brahmer and Harmatys, 2009; Bilgin and Geban, 2004; Dellalbasi, 2012; 
Doymuş et al., 2004; Gelici 2011; Ozdoğan, 2010; Ozsarı 2009; Ozyurt, 2013; Saritas, 2002; Tsay and Brady, 2010; Unlu and Aydintan, 2011).

Today, it is observed that models which activate students in the learning environment and increase the overall level of success in classroom come forward in educational systems. Cooperative learning, the leading one of these models, has a large number of techniques that can be applied from the primary contexts to the undergraduate level. Literature survey (Arisoy, 2011; Arslan and Sahin, 2004; Cirakoglu, 2009; Doymus et al., 2004; Efe, 2011; Ertekin, 2001; Gulsar, 2014; Johnson et al., 2000; Karaoglu, 1998; Marangoz, 2010; Ozsari, 2009; Ozyurt, 2013; Saritas, 2002; Ural, 2007, Unlu, 2008; Vaughan, 2002; Yildiz, 2001; Zenginobuz, 2005) indicates that Student Teams Achievement Divisions (STAD) devised by Slavin in 1970s and Learning Together (LT) technique developed and improved by Kurt Lewin, Morton Deutsch and Johnsons in the mid-1960s are widely being used in Mathematics and Science classes.

As another result of the literature survey, no researches are found in the subjects of Analytic Geometry regarding the implementation of cooperative learning at bachelor's degree. Therefore; this present study is expected to contribute to the field. In addition, it is expected that refreshing and enriching pre-service teachers' knowledge and experience which they have already accumulated throughout their academic live sand transferred to university education, their reflection of strategies and techniques they learn to their career, sufficient information and equipment they are provided during their undergraduate training will improve the quality of education provided in schools. It is thought that cooperative learning methods followed in the study will help to overcome pre-service teachers' shortcomings related to the methods used in teaching activities during their undergraduate education. This study examines the impact of materials designed according to STAD and LT techniques of cooperative learning method and lectures in accordance with these techniques on preservice teachers' academic achievement and retention levels in the subject of Analytic Geometry. The results of the study are expected to contribute to maths teachers and people who are interested in this field in terms of the promotion of cooperative learning. Additionally, this study will help increase pre-service teachers' awareness on the subject and contribute to improve their social relations

This study tries to determine the effects of Student Teams Achievement Divisions (STAD) and Learning Together (LT) methods used in cooperative learning on pre-service primary school maths teachers' academic achievement regarding the subject "Analytic Examination of the Circle" and retention levels of the knowledge acquired. Within this context, the main problem statement of the research is as follows: "Is there a significant difference between the traditional teaching method and cooperative learning method regarding the subject 'Analytic Examination of the Circle' in terms of pre-service primary school maths teachers' academic achievement and retention level of the knowledge acquired?"Answers to the following sub-problems are sought.

1. Is there a significant difference between pre-testand post-test scores of pre-service primary school maths teachers regarding the subject 'Analytic Examination of the Circle'?

2. Is there a significant difference between traditional teaching method and cooperative learning methods(STAD and LT) on the retention level of the knowledge they acquired regarding the subject 'Analytic Examination of the Circle'?

3. Which of the methods used in teaching the subject of 'Analytic Examination of the Circle' is more effective on the development of pre-service teachers?

\section{Method}

\section{Research Model}

In this research Quasi-experimental research design is used which is appropriate to determine whether teaching materials or methods have the intended effect on participants in different schools or classes. In this type of design, classrooms are included in the study for an educational purpose (Karasar, 2005; McMillan and Schumacher, 2006).The main objective of the experimental design isto test the causal relationship created between the variables (Buyukozturk et al., 2010).For this reason, this research utilizes quasi-experimental pretest-posttest design with a control group. Quasi-experimental model is often used in conditions where it is impossible, very difficult or sometimes unnecessary to create randomized experimental and control groups (Basturk, 2009).Classes which followed collaborative teaching methods form "Experimental Groups" while students in classes where teacher-centered teaching methods are used in teaching constitute "Control Group." The experimental design of study is given Table 1. 
Table1.Experimental design used in the research

\begin{tabular}{|c|c|c|c|c|}
\hline Group & Pretest & Procedure & $\begin{array}{l}\text { Post } \\
\text { Test }\end{array}$ & $\begin{array}{c}\text { Retention } \\
\text { Test }\end{array}$ \\
\hline Exp.1 & $x$ & $\begin{array}{c}\text { Student Teams } \\
\text { Achievement Divisions }\end{array}$ & $x$ & $x$ \\
\hline Exp. 2 & $x$ & Learning Together & $x$ & $x$ \\
\hline $\begin{array}{c}\text { Control } \\
\text { Group }\end{array}$ & $x$ & Traditional Teaching & $x$ & $x$ \\
\hline
\end{tabular}

\section{Subjects}

The sampling of the study is comprised of 76 pre-service teachers studying in 3rd grade in normal and evening education groups at the Department of Primary School Mathematics Teaching in a public university. Students in the working group were chosen using appropriate sampling method. Experimental studies can be carried out by selecting two groups (classes) data out of groups which seem relatively most identical to each other considering some data (Buyukozturk, 2010).In this research the average grades regarding the course 'Analytic Geometry I' of the students in 3 branches were first examined, and because they were found to be very close to each other, two of them were randomly designated as 'experimental groups' and one other was chosen as 'Control group'. The study was conducted by the researcher in each group.

\section{Data Collection Tools}

'Achievement Test for Analytical Examination of the Circle "and "Module Tests' developed by the researchers were used to collect data in this study. The relevant literature was surveyed for this study which aims to determine the effects of cooperative learning methods on pre-service teachers' academic achievement and retention levels of the knowledge acquired regarding the subject "Analytic Examination of the Circle " in undergraduate level. Multiple choice and open-ended questions were included in the academic achievement test after consulting a mathematics education specialist holding doctoral degree in this field.A table of specifications regarding the analytical examination of the circle (15 items) was prepared considering acquirements in Analytical Geometry curriculum prepared by The Board of Education and Discipline (TTK in Turkish), Bologna process learning outcomes, and Geometry and Analytic Geometry textbooks.

48 items regarding the analytical examination of the circle were developed according to the table of specifications prepared. These items were administered as a pilot study to 73 students who have previously taken Analytic Geometry courses and the total scores each student obtained in the test were calculated. While calculating the test points, correct answer for each question was calculated as 4 points. In scoring of openended questions was used Holistic Rubric for Solving Problems (Ministry of National Education, MoNE, 2011). Indices of difficulty and discrimination for test items were calculated. Item indices of multiple choice questions included in the achievement test were calculated according to Tosun and Taskesenligil(2011) while item analyses for the open-ended questions were done according to Bayrakceken (2008).Taking the available information into account, items included in the test in pilot study were revised. A total of 15 questions were excluded from the test because they were found to have an index of discrimination under .20 and 5 of the remaining open ended questions were included into 2 of the 8 open ended questions as sub-questions. Overall item difficulty index was found to be .582 and index of discrimination was calculated as .344 in the test.

For the provision of content validity, the remaining questions along with the table of specifications were delivered to two experts working in the field of mathematics education and one teacher currently working in an Anatolian high school for expert judgment. As a result of the feedback received, an achievement test consisting of 8 open-ended and 20 multiple-choice questions for the analytical examination of the circle was constructed. It is essential to check and analyze the reliability of the test in order to ensure that measurement results of the test items obtained are error-free and items are consistent with each other. Frisbee (1988) purports that Cronbach's alpha coefficient is the most ideal method for reliability of the tests consisting of open-ended and multiple choice questions. Reliability analysis was conducted on data obtained from the pilottest and Cronbach's alpha value was calculated as $\mathbf{. 7 8 4}$. A high reliability of the test indicates that the error involved in the test is little; a low reliability, however, suggests that the error involved in the test is much (Ozcelik, 2010). 
Open-ended questions on the achievement test used in the pilot test assessed and evaluated by the researcher and another expert in mathematics education utilizing Holistic Rubric for Problem Solving (MoNE, 2011), then inter-rater reliability was calculated for each question and Kappa coefficient of aggreement for these rater scores obtained was calculated as .862. This finding regarding the assessment of coefficients indicates 'almost perfect aggreement' according to Landis and Koch (1977).

In the study, in order to follow the development of pre-service teachers, module tests -7 multiplechoice and 4 open-ended questions regarding the topics to be covered each week- prepared considering the criteria taken into account when constructing the achievement test were utilized. After the questions were prepared, they were submitted to an expert in mathematics education and necessary modifications and corrections were made taking into consideration the feedback received. Later,module tests were administered to students who have taken the relevant course previously and studying in their final year at the Department of Primary School Maths Teaching and reliability of the test measurements wasanalyzed. Coefficients of reliability of module testswere calculated by using "Cronbach's Alpha" formula in SPSS. Coefficients of reliability of the module tests were calcualted as follows: .69 for Test onEquations of Circles, .62 for Test on Exceptions inCircles, 71 for Test on Circlesand Lines,.66 for Test on Tangent lines in Circles and Normal Equations, .74 for Test on Conditions for Two Circles,.61 for Test on Conditions for One Point and aCircle - Power - Power axis, and .76 for Test on Family of Circles - Semicircle - Inequalities.

\section{Procedure}

In the first week of the study, participants were informed and delivered a briefing about the procedures, and a pre-test was administered to experimental groups and control group. Implementation phase of the study lasted 7 weeks ( 21 hours). At the end of the implementation phase, an achievement test was administered to experimental and control groups as the post-test. One month after the post-test, the experimental and control groups were administered a retention test. Participants in each group are shown in group diagram using initials of their names and surnames. Distinct codes are assigned to each participant in the group diagram. The groups created were requested to choose a head of group and a spokesperson.

\section{STAD Implementation:}

In a lesson a week before starting research on teachers in the first experimental group, a briefing session was organized for all students in order to explain the implementation procedure of the Student Teams Achievement Divisions (STAD) method, how to evaluate the studies and expectations from the participants. After determining the class to implement this method, student teams were formed. Pre-service teachers' pretest results for 'Achievement Test for Analytical Examination of the Circle" were taken into consideration for the formation of student teams. Pre-service teachers' names were listed in descending order according to their pre-tests results, and heterogeneous teams were formed by writing letters A, B, C, D, E, F and G forward and back from the top to the last student in the list. Six teams of four people and one team of five people were formed in that class comprised of 29 students. It was paid attention that every team included people at different levels of achievement.

After all pre-service teachers comprehended the procedures and their responsibilities, the instruction was started. In the first hour of Analytical Geometry course, three hours a week, the subject of the week was presented in detail by the researcher using narration, question-answer and discussion techniques in class, and participants were reminded of the preliminary knowledge they need to know. Pre-service teachers were often asked questions about the subject and random participants were asked to answer. In the second hour of the lesson, teams were delivered worksheets about the subject they were taught and asked to work it together again with their friends in group. These worksheets were comprised of questions which were more challenging and exploration-oriented or may require proof and discussion. The group (Group A only) was provided one or two papers in order to encourage group members to work collaboratively. During group work, the researcher walked around and observed the groups, and provided help to complete missing points he noticed. Ten minutes prior to the end of the lesson, Answers to the worksheets were given and participants were provided time to review and discuss about their mistakes if they had. In the third hour of the week, all students in teams individually participated in the formative exam done after they completed learning as teams.

\section{Learning Together Implementation:}

Learning Together method was applied in the second experimental group of the research. The class was divided into five heterogeneous cooperative groups, three of which included five members while next two groups were comprised of four members each by taking their pre-test results for 'Achievement Test for 
Analytical Examination of the Circle". Groups were given names and the members of the group were assigned a code. Group members are shown in group diagram using initials of their names and surnames.

In a lesson a week before starting research, a briefing session was organized for all students in order to explain the implementation procedure of the Learning Together (LT) method, how to evaluate the studies and responsibilities of the participants. During implementation phase of the Learning Together (LT) technique, before the group works, students were delivered lecture notes regarding seven sub-headings of the subject covered in the research. Lecture notes / booklets covering different subheadings were studied each week and the implementation phase was completed in a total of seven weeks. Three hours were allotted to the subject to be studiedeach week. Each group member in the class, where LT methods were applied, was given various assignments related to the subject to be studied next week and asked to write reports about the assignments. By giving assignments and duties regarding the subject to be taught each week previously, group members were aimed to be in the class ready and prepared. In the first hour of the courses an appropriate environmentwas createdfor group members to be and work together. Then, the groups presented their group assignments they prepared in relation to the subject and activities regarding that subject in groups, asked questions and discussed on the subject.In order to provide positive interdependence and encourage students to work together, each group was given one worksheet. After this phase, one group was determined by lot, and they were asked to present the assignment and activities regarding the subject in the class.As soon as that group completed their presentation, questions were received from other groups and necessary discussion was made on the subject.Afterwards, a second group out of remaining groups was selected by lot and was asked to explain the subject to the class in the same way. While they were presenting their assignments, researcher reminded the missing points and took the necessary measures in order to make learners understand the subject better.

\section{Traditional TeachingImplementation:}

Teaching of the subjects in the class designated as the control group was carried out according to traditional teaching methods. In the control group, subjects studied were presented by the researcher using plain narrative techniques, example questions were solved on the board and students were provided some time to individually solve the other example problems. Then, a volunteer student was asked to present solution on the board. As the lecture took place, students were asked several questions by the researcher where considered necessary and researcher either continued teaching or preferred review and revision, according to the responses received. When there were questions not solved by students, the researcher provided clues and strived to redirect students to the solutions. It was considered to provide procedures such as immediate feedback and reinforcements. In addition, examples solved during the lesson were paid attention to be the same as those solved in the experimental groups. At the end of the lesson, students were given homework on the subject discussed in class. While beginning the next lesson, the researcher strived to present and discuss the solutions about the questions, as many as possible, which students could not do at home, and did an overall review and revision of the previous lesson.

\section{Data analysis}

In the analysis of quantitative data obtained in this research SPSS v.18 (Statistical Package for the Social Sciences) softwarewas utilized and the results were evaluated at .05 level of significance.Pre-test, post-test, retention test and module tests as formative test scoresof the experimental and control groups were compared both within themselves and others. In order to apply parametric tests such as t-test, ANOVA or ANCOVA to the data obtained in any kind ofstudy, it is required that data are at least interval scale and normally distributed, and the variances of the groups involved, in case of multiple groups (Can, 2014).Therefore; in the study, it was first analyzed whether the obtained data are normally distributed or not. Owing to the fact that experimental groups and control group of the researchinclude participants less than 30, Shapiro-Wilk test was utilized to test whether their scores are normally distributed. Assumption of equality of variance, though, was assessed by Levene Test. If significance value is $p>.05$ in Shapiro-Wilk test, it indicates normal distribution. If $p$-value of Levene test is $p>.05$, it is then interpreted that variances are equal (Can, 2014).In the analyses of normally distributed data in this research, t-test, ANOVA and LSD testwere used for multiple comparisons between groups. 


\section{Findings}

\section{Findings as results of first sub-problem}

The first sub-problem of the research is stated as "Is there a significant difference between pre-test and post-test scores of pre-service primary school maths teachers regarding the subject 'Analytic Examination of the Circle'? Descriptive statistics and test of normality results obtained as a result of the analysis of the groups' pretest and post test scores are presented in Table 3.

Table 3.Descriptive statistics and test of normality results regarding the groups' pre-test and post-test scores

\begin{tabular}{|c|c|c|c|c|c|c|c|c|c|c|c|}
\hline \multirow{2}{*}{ Tests } & \multirow{2}{*}{ Group } & \multirow{2}{*}{$\mathrm{N}$} & \multirow{2}{*}{$\bar{X}$} & \multirow{2}{*}{ SD } & \multicolumn{3}{|c|}{ Shapiro-Wilk } & \multicolumn{4}{|c|}{ Levene } \\
\hline & & & & & Statistic & $\mathrm{df}$ & Sig. & Statistic & df1 & df2 & Sig. \\
\hline \multirow{3}{*}{$\begin{array}{l}\text { Pre- } \\
\text { Test }\end{array}$} & Exp. 1 & 29 & 56.93 & 14.293 & .957 & 29 & .271 & \multirow{3}{*}{.431} & \multirow{3}{*}{2} & \multirow{3}{*}{73} & \multirow{3}{*}{.651} \\
\hline & Exp. 2 & 23 & 53.61 & 15.284 & .935 & 23 & .138 & & & & \\
\hline & Control & 24 & 50.00 & 12.087 & .979 & 24 & .872 & & & & \\
\hline \multirow{3}{*}{$\begin{array}{l}\text { Post- } \\
\text { Test }\end{array}$} & Exp.1 & 29 & 111.48 & 9.230 & .932 & 29 & .064 & \multirow{3}{*}{2.617} & \multirow{3}{*}{2} & \multirow{3}{*}{73} & \multirow{3}{*}{.080} \\
\hline & Exp. 2 & 23 & 105.00 & 16.181 & .949 & 23 & .276 & & & & \\
\hline & Control & 24 & 93.75 & 13.241 & .947 & 24 & .234 & & & & \\
\hline
\end{tabular}

As observed in Table 3, as results of the pre-test done to determine the achievement level of the groups on 'Analytical Examination of the Circle' prior to the application, the means were calculated as $\bar{X}=56.93$ for Experimental Group 1 where STAD method was followed, $\bar{X}=53.61$ for Experimental Group 2 where LT method was followed and $\bar{X}=50.00$ for the Control Group. With respect to the Shapiro-Wilk test results, as $p$ value for all group is $p>.05$, it indicates that data are normally distributed. Besides, owing to the fact that $p$ value is $p>.05$ according to Levene test, there exists no significant difference between the variances.

And also as a result of a post-test administered to determine the achievement levels of the experimental and control groups regarding the 'Analytic Examination of the Circle' after the application, the means were calculated as $\bar{X}=111.48$ for Experimental Group 1 where STAD method was followed, $\bar{x}=105.00$ for Experimental Group 2 where LT method was followed and $\bar{X}=93.75$ for the Control Group. Because $p$ value for all groups is $p>.05$ in Shapiro-Wilk test results, data are normally distributed. Besides, owing to the fact that $p$ value is $p>.05$ according to Levene test, there exists no significant difference between the variances

Therefore; assumptions for ANOVA test for independent samples can be ensured for pre-test and post-test. ANOVA test results are presented in Table 4.

Table4. Results for ANOVA Test applied to the groups' pre-test and post-test scores

\begin{tabular}{ccccccc}
\hline \multirow{2}{*}{ Tests } & Source & Sum of Squares & $\mathrm{df}$ & Mean Square & $\mathrm{F}$ & Sig. \\
\hline \multirow{3}{*}{ Pre-Test } & Between groups & 631.397 & 2 & 315.698 & 1.621 & .205 \\
& Within groups & 14219.340 & 73 & 194.785 & & \\
& Total & 14850.7 & 75 & & & \\
\multirow{3}{*}{ Post-Test } & Between groups & 4167.785 & 2 & 2083.892 & 12.492 & .000 \\
& Within groups & 12177.741 & 73 & 166.818 & & \\
\hline
\end{tabular}

When findings regarding the ANOVA test for independent samples applied tomean pre-test scores for 'Achievement Test for Analytical Examination of the Circle' of the groups, presented in Table 4, are analyzed, it is observed that there exists no statistically significant difference between groups $\left(F_{(2,73)}=1.621 ; p>.05\right)$. In order an experimental study to give healthy outputs, it is anticipated that prior knowledge of the experimental and control groups is at the same level. The findings obtained above indicate that there exists no significant 
difference between the achievement levels of the students in the experimental and control groups in terms of knowledge about the unit studied prior to the application.

According to data presented in Table 4, One-way analysis of variance (ANOVA) for independent samples was used to compare the post-test mean scores of the groups participated in the study regarding the 'Analytic Examination of the Circle'. When post-test results are examined, it is observed that there exists statistically significant difference between groups $\left(F_{(2,73)}=12.492 ; p>.000\right)$. In order to identify between which groups there is a significant difference, LSD multiple comparison test was used to compare the experimental groups and control group.

When data are analyzed, it was found that there is no significant difference between EXP.1 which followed STAD technique and EXP. 2 which followed LT technique in terms of post-test scores. However, there are significant differences between experimental groups and control group which followed traditional teaching methods. As Table 3.5 displays, academic achievement scores of the students in STAD group have a difference of 6.483 between that of those in LT group and a difference of 17.783 between that of students in CONTROL group.

As a result of tests applied to post-test scores, it is observed that students in EXP.1 which followed STAD technique have been more successful than both students in EXP. 2 which followed LT technique and those in CONTROL group which followed traditional teaching methods. It can be considered that the presentation made by the teacher during the implementation phase of the STAD method and students' review of the lesson after the presentations have been significantly effective.

\section{Findings as results of second sub-problem}

The second sub-problem of the research is stated as "Is there a significant difference between traditional teaching method and cooperative learning methods on the retention level of the knowledge they acquired regarding the subject 'Analytic Examination of the Circle'?'Descriptive statistics and test of normality results obtained as a result of the analysis of the groups' post-test scores are presented in Table 5.

Table 5.Descriptive statistics and test of normality results regarding the groups' test scores in Retention test

\begin{tabular}{|c|c|c|c|c|c|c|c|c|c|c|}
\hline \multirow{2}{*}{ GROUP } & \multirow{2}{*}{$\mathrm{N}$} & \multirow{2}{*}{$\bar{X}$} & \multirow{2}{*}{ SD } & \multicolumn{3}{|c|}{ Shapiro-Wilk } & \multicolumn{4}{|c|}{ Levene } \\
\hline & & & & Statistic & $d f$ & Sig. & Statistic & df1 & df2 & Sig. \\
\hline Exp. 1 & 29 & 110.14 & 9.716 & .938 & 29 & .087 & & & & \\
\hline Exp. 2 & 23 & 112.52 & 11.548 & .960 & 23 & .464 & .219 & 2 & 73 & .804 \\
\hline Control & 24 & 103.88 & 10.784 & .969 & 24 & .636 & & & & \\
\hline
\end{tabular}

As observed in Table 5, according to the results of the retention test regarding the 'Analytic Examination of the Circle' which was administered one month after the application, the means were calculated as $\bar{X}=110.14$ for Experimental Group 1 where STAD method was followed, $\bar{X}=112.52$ for Experimental Group 2 where LT method was followed and $\bar{X}=103.88$ for the Control Group. Since $p$ value for all groups is found to be $p>.05$ in Shapiro-Wilk test results, data are normally distributed. Besides, owing to the fact that $p$ value is $p>.05$ according to Levene test results, there exists no significant difference between the variances. Therefore; assumptions for ANOVA test for independent samples can be ensured. In order to determine whether there is a significant difference between groups, One-Way Analysis of Variance (ANOVA) was utilized and findings are presented in Table 6. 
Dirikli ve Akgün - Çukurova Üniversitesi Eğitim Fakültesi Dergisi, 46(2), 2017, 427-440

Table6. Results for ANOVA Test applied to the groups' test scores in Retention test

\begin{tabular}{lccccc}
\hline \multicolumn{1}{c}{ Source } & Sum of Squares & $\mathrm{df}$ & Mean Square & $\mathrm{F}$ & Sig. \\
\hline Between groups & 952.122 & 2 & 476.061 & 4.211 & .019 \\
Within groups & 8251.812 & 73 & 113.039 & & \\
Total & 9203.934 & 75 & & & \\
\hline
\end{tabular}

One-way analysis of variance (ANOVA) for independent samples was used to compare the mean scores of the groups participated in the study regarding the retention test for 'Analytic Examination of the Circle' and observed that there exists statistically significant difference between groups $\left(F_{(2,73)}=2.211 ; p>.05\right)$. In order to identify between which groups there is a significant difference, LSD multiple comparison test was used to compare the experimental groups and control group.

When data are examined, it is found that there is no significant difference between experimental groups. However, there are significant differences between experimental groups and CONTROL group. According to these findings, retention test scores of the students in EXP.2 group have a difference of 2.384than that of those in EXP.1 group and a difference of 8.647 than that of students in CONTROL group.

Although EXP.1 which followed STAD method is the most successful group according to post-test scores, students in EXP. 2 which followed LT technique are found to be the most successful according to the analyses applied to retention test scores. This finding can be considered as a result of the fact that students in LT group come together, review course materials and get ready before the lesson and do revision during the application procedures.

\section{Findings Regarding the Module Tests}

As the third sub-problem of the research, answer for the question stated as "Which of the methods used in teaching the subject of 'Analytic Examination of the Circle' has been more effective on the development of pre-service teachers?"was sought. In order to find and answer to this question, arithmetic mean scores for the module tests administered regarding the lesson taught in both experimental groups and control group after the subject was covered each week during the application process are presented in Table 7.

Table 7.Mean scores for the Module tests

\begin{tabular}{lccccccc}
\hline Group & Module1 & Module2 & Module3 & Module4 & Module5 & Module6 & Module7 \\
\hline Exp. 1 & $\mathbf{3 1 . 7 0}$ & 31.79 & $\mathbf{2 9 . 5 5}$ & $\mathbf{3 2 . 4 6}$ & $\mathbf{3 3 . 3 4}$ & $\mathbf{4 1 . 8 2}$ & $\mathbf{2 4 . 7 6}$ \\
Exp. 2 & 30.04 & $\mathbf{3 3 . 4 3}$ & 27.90 & 31.09 & 31.26 & 40.82 & 23.68 \\
Control & 29.00 & 29.45 & 22.19 & 24.65 & 25.42 & 36.45 & 21.21 \\
\hline
\end{tabular}

In this research, the experimental groups and control group were administered module tests covering the subject taught each week and their learning levels on a weekly basis weretriedto be monitored. According to the data in Table 7, the mean scores of the experimental groups in all module tests appear to be higher than those of the control group. It is observed that EXP. 2group has the highest mean score in Module Test 2 while EXP. 1 group has the highest scores in all remaning module tests. It is understood that the CONTROL group has the lowest scores in all module tests.

When these findings regarding the module tests are analyzed, they indicate that cooperative learning methods have been more effective on the development of pre-service teachers. As for the results in the experimental groups, STAD group is found to be more successful in six of the module tests while LT group has the highest scores in only one test.

\section{Results and Discussion}

This study tries to determine the effects of teaching utilizing Student Teams Achievement Divisions (STAD) and Learning Together (LT) techniques of cooperative learning methods on pre-service primary school maths 
teachers' academic achievement and retention levels of the knowledge acquired regarding the subject "Analytic Examination of the Circle", one of the topics in "Analytical Geometry" course which is taught junior students studying at The Department of Primary School Maths Teaching. To this end, students' level of knowledge before the application, their development level during the application, and students' level of knowledge after the application. Additionally, retention level of the knowledge acquired was measured one month after the applications were measured. Based on the analyses of the data obtained as results of the tests administered before, during and after the application, the following conclusions were reached.

There exists no statistically significant difference between academic achievement pre-test scores of participants in experimental groups followed cooperative learning method and students in the control group which followed traditional teaching method. This finding indicates that three groups are equivalent and have the same level of readiness before the start of the application. Keeping all the conditions equivalent in order to follow STAD and LT techniques of cooperative learning methods is something required and essential for interpretation of other sub-problems as it provides convenience.

It is observed through the findings obtained from the statistical analyses of academic achievement post-test scores of the students participated in the research that STAD, LT and traditional teaching methods followed in groups increase academic achievement, when compared to students' pre-test scores. According to the results of ANOVA test applied to post-test scores, academic achievement of the students in experimental groups seems to be higher than academic achievement of those taught by traditional teaching method. According to these findings, it can be said that cooperative learning techniques and traditional teaching methodused within this research make a positive impact on academic achievement of the students. In this case, the level of significance between post-test achievement scores of the experimental and control groups appears to be of great importance in order to determine which method is more effective on the academic achievements of students. According to LSD multiple comparison test results, students in experimental group which applied STAD technique seem to be more successful than other groups in which LT and traditional teaching methods were followed. This finding corresponds with the finding that cooperative learning methods are more effective on academic achievement of students when compared to the traditional teaching method (Akbuga,2009; Bilgin, 2004; Cirakoglu, 2009; Efe, 2011; Eskiturk, 2009; Gulsar, 2014; Marangoz, 2010; Ozsari, 2009; Tarim \&Akdeniz, 2008;Ural, 2007; Unlu, 2008;Vaughan, 2002;Zenginobuz, 2005)

In addition, Slavin (1991) concludes in 11 of his 14 research that STAD is more effective than traditional methods. In his research examining the impact of STAD technique on high school students' achievement in Geometry lesson, Morrow (1994) finds out that STAD technique appears to be an effective in-class teaching method and students in groups which follow this technique in teaching shows higher achievement. Tarim (2003) investigates 31 studies on the impact of cooperative learning methods on academic achievement and reveals that STAD technique is the most widely used technique. Likewise, Gencosman (2011), in his study focusing on the impact of STAD cooperative learning technique on students' academic achievement, selfefficacy, retention and test anxiety levels regarding the Science and Technology course, reveals that students who participate in educational activities carried out according to the cooperative learning techniques can keep knowledge in mind longer. Johnson, Johnson and Stanne (2000) compare and contrast the most widely used eight cooperative learning techniques in a meta-analysis study in terms of (a) ease of learning the method,(b) ease of initial use in the classroom, (c) ease of long-term maintenance of use of the method,(d) robustness of the method, and (e) adaptability of method to changing conditions. They find out that STAD seems to be more advantageous with respect to ease of learning and ease of initial use; and LT is more effective when compared to individualistic learning.

Saritas (2002), in his research using LT technique, concludes that that students in the experimental group are more successful in terms of the achievement level in classrooms cooperative and traditional methods were applied.According to the results of a research by Varank and Kuzucuoglu (2007), average achievement scores of the students who are taught by LT technique seem to be higher than that of students taught by traditional methods.Again, Aksoy (2011), Ergun (2006), Ertekin (2001), Karaoglu (1998), Ozyurt (2013) and Yıldız (2001) observe in their researches that LT techniqueis more effective in increasing academic achievement of the students when compared to traditional methods. These results support finding obtained in this research that STAD and LT methods are found to be more effective in increasing learners' academic achievement in comparison to the traditional teaching method. In cases where cooperative learning methods are generally used, another finding (Bozkurt 1999) that students get higher points in both verbal and written exams is also consistent with the results obtained here. 
At the end of the implementation phase, three groups were administered an academic achievement test as a post-test.A month after the post-test, the same test was taken as a retention test to measure to what extent the knowledge is kept in mind.As a result of the tests applied to the retention test scores of the experimental groups which STAD and LT techniques of cooperative learning were followed and the control group which followed traditional teaching method, a significant difference was observed in favor of the experimental groups. Karaoglu (1998) investigates the effects of traditional instruction and cooperative learning on fifth graders' achievement and retention levels in Social Scienceslesson, and observes that students in cooperative learning groups are more successful than students in traditional learning groups. Nakiboğlu (2001)demonstrates in her study, which examines whether cooperative learning affects student achievement and recall, that cooperative learning increases achievement and students' level of achievement appears to be statistically high even it's after a period of four months. Hevedanli et al. (2004) conclude that when compared to those in the control group which followed traditional teaching methods, students in the experimental group whichfollowed cooperative learning are more successful, in terms of post-test results and retention test scores. Unlu (2008) studies the impact of cooperative learning on primary school 8th grade students' academic achievement and retention regarding the subject entitled "Permutations and Combinations" in Mathematics, and draws conclusions according to the findings of the research that cooperative learning is more effective than traditional learning methods and students in the experimental group bear the subjects they learn in their mind longer. In addition, this finding seems similar and supports other research examining the impact of cooperative learning on retention in literature (Arisoy, 2011; Buzludag, 2010; Komurkaraoglu, 2011; Pinar, 2007; Tanel, 2006; Torun, 2009; Uygur, 2009) with respect to the finding that retention of the knowledge acquired in cooperative learning classes is much longer.

Activities regarding the cooperative learning should often be given place in teaching Analytical Geometry, and teachers and pre-serviceteachers should be informed about such activities. Additionally, they should be encouraged about the applicability of the method.In order to increase the validity of research results regarding the effectiveness of Cooperative learning method and its techniques and to make more accurate generalizations, cooperative learning techniques can be compared within themselvesand with other learning methods excluding the traditional learning method. 


\section{References}

Akar, M. S. (2012). Informing of Science and Technology Teachers About Cooperative Learning Model, Applications of This Model in The Class and Evaluating The Obtained Results: (Kars Sample). PhD Thesis, Atatürk University, Erzurum.

Akbuga, S. (2009). The Effect of Group Activities Structuredaccording to Cooperative Learning Principles on Students'level at The Beginning and at the End and Attitudes in 4th Grade Mathematics Lesson in Primary School. Unpublished Master's Thesis, Dokuz Eylul University, Izmir.

Akpınar, B. and Gezer, B. (2010). Learner-Centered New Educational Paradigms and Their Reflections on The Period of Learning and Teaching. Dicle University Journal of Ziya Gökalp Faculty of Education, 14, 1-12.

Aksoy, G. (2011). Effects of Reading-Writing-Application and Learning Together Methods on Students' Understanding of Laboratory Experiments in Science and Technology Course. Master's Thesis, Atatürk University, Erzurum.

Arısoy, B. (2011). The Effects of Stad and Tgt Techniques of Cooperative Learning on Sixth Grade Students' Academic Achievement, Retention and Social Skill Levels in "Statistic and Probability" Subject in Mathematics Lesson. Unpublished Master's Thesis, Cukurova University, Adana.

Arslan, A. and Sahin, T. Y. (2004). The Effects of Cooperative Learning Based on Constructivist Learning on Students' Affective Learning. XIII. National Educational Sciences Congress, Inonu University, Malatya.

Avsar, Z. and Alkıs, S. (2007), The effect of cooperative learning "Jigsaw I" technique on student success in social studies course. Elementary Education Online (EEO), 6(2), 197-203.

Bayrakceken, S. (2008). Test Geliştirme. Edt. E. Karip. Ölçme ve Değerlendirme, 244-277, Pegem A, Ankara.

Basturk, R. (2009). Deneme Modelleri., A. Tanrı̈̆ğen. (Editör).Bilimsel Araştırma Yöntemleri. Ankara. Anı Yayıncılık, Ss.31.

Bilgin, T. (2004). The Usage of Student Teams and Achievement Divisions and Technical Results of Application on Seventh Grade in Elementary Mathematics Course (Regarding polygons). Uludag University Faculty of Education Journal, 17(1): 19- 28.

Bilgin, I. and Geban, O. (2004). Investigating The Effects of Cooperative Learning Strategy and Gender on ReService Elementary Teacher Students' Attitude Toward Science and Achievement of Science Teaching Class I, Hacettepe University Journal of Education, 26, 9-18.

Bozkurt, Y. (1999). The Effects of Various Assessment Methods for Measuring for Measuring Achievement in Cooperative Learning Group at Fourth Grade Elementary Mathematics. Unpublished Master's Thesis, Hacettepe University, Ankara.

Brahmer, K. and Harmatys, J. (2009), Increasing Student Effort in Complex Problem Solving Through Cooperative Learning and Self Recording Strategies.

Buzludag, P.(2010). The Effects of Teaching with Cooperative Learning of Unit of Reproduction on Livings on Achievement in Science Lesson. Master's Thesis, Fırat University, Elazığ.

Buyukozturk S. (2010).Sosyal Bilimler Içcin Veri Analiz El Kitabı, Pegem A Akademi, Ankara.

Can, A. (2014). Spss ile Bilimsel Araştırma Sürecinde Nicel Veri Analizi. Pegem Akademi Yayınları, Ankara.

Calıskan, F. (2005). The Effect of Active Learning Methods of Analysis Story on Academic Success, Attitude, Level of Active Learning of Primary School Fourth Class Student in Social Study.Unpublished Master's Thesis, Mustafa Kemal University, Hatay.

Cirakoglu, C. (2009). The Effects of Cooperative Learning and Traditional Learning Approaches on 6th Grade Students' Academic Achievements in Geometry Course. Master's Thesis, Gazi University, Ankara.

Dellalbası, O. (2012). The Effects of Jigsaw and Group Research Techniques to Academic Succes of The Eight Grade Elementary Students. Master's Thesis, Atatürk University, Erzurum.

Doymus, K., Simsek, U., \&Bayrakceken, S. (2004). The Effect of Cooperative Learning Method on Attitude and Academic Achievement of Science Lessons. Journal of Turkish Science Education (TUSED), 1(2), 103115.

Duru, A. (2010). The experimental teaching in some of topics geometry. Educational Research and Review, 5(10), 584-592.

Efe, M. (2011). The Effects of Cooperative Learning Method of Students? Teams- Achievement Divisions and Team Assisted Individualization Instructions on Students? Attitudes, Achievement and Motivation at Primary 7th Grade 'Statistics and Probability? Units on Mathematics Course. Master's Thesis, Mustafa Kemal University, Hatay.

Ergun, A. (2006). The Effects of Cooperarive Learning on Eight Grade Elementary Science Teaching. Master's Thesis, Pamukkale University, Denizli. 
Ertekin, B. (2001). The Effects of Traditional and Cooperative Learning Methods on the Science Teaching. Master's Thesis. Pamukkale University, Denizli.

Eskiturk, M. (2009). "The Effect of Cooperative Learning Activities, Which Take the Base Critical Thinking Ability, to Academic Success in Social Science. Master's Thesis. 18 March University, Çanakkale.

Frisbie, D. A. (1988). Reliability of Scores From Teacher-Made Tests. Educational Measurement: Issues And Practice, 7(1), 25-35.

Gelici, O. (2011). The effect of the Cooperative Learning Techniques on the Seventh Grade Students' Achievement, Attitude and Critical Thinking Skills in Mathematics Course Algebra Learning Space. Unpublished Master's Thesis, Mustafa Kemal University, Hatay.

Gencosman, T. (2011). The Effects of Using the Student Teams Achievement Divisions Technique in Science and Technology Education on Students? Self-Efficacy, Test Anxiety, Academic Achievement and Retention. Master's Thesis, Akdeniz University, Antalya.

Gomleksiz, M. (1997). Kubaşık Öğrenme: Temel Eğitim Dördüncü Sınıf Öğrencilerinin Matematik Başarısı ve Arkadaşlık iliş̧kileri Üzerine Deneysel Bir Çalışma. Adana: Baki Kitap ve Yayınevi.

Gulsar, A. (2014). The Effects of Cooperatıve Learnıng on Mathematıcs Achievement and Students' Views Concernıng the Method. Master's Thesis, Uludağ university, Bursa.

Hevedanlı, M., Oral, B.\& Akbayın, H. (2004). The Effects of Cooperative Learning and Traditional Teaching Methods on Students' Achievement and Retention in Teaching Biology. XIII. National Educational Sciences Congress, Inonu University, Malatya.

Johnson, D.W., Johnson, R.T., \& Stanne M.B. (2000). Cooperative Learning Methods: A Meta analysis.

Karaoglu, I. B. (1998). The Effects of Traditional Teaching Methods and Cooperative Learning on Student Achievement, Retention and Classroom Management. PhD Thesis, Dokuz Eylül University. Izmir.

Karasar, N. (2005). Bilimsel Araştrıma Yöntemleri. 15. Baskı. Ankara: Nobel Yayın Dağıtım, 292 S.

Komurkaraoglu, S. (2011). The Effect of Cooperative Learning Method on Student Achievement and Continuance Level of Knowledge in Teaching the Light and Sound Unit That is in Science and Technology Course at 6th Grade in Primary Education. Master's Thesis, Kastamonu University.

Landis J.R and Koch G.G (1977). The Measurement of Observer Agreement for Categorical Data, Biometrics, 33, 159-174.

Marangoz, I. (2010). The Effects of Cooperative Learning Method on the Achievement and the Attitudes of Students in Primary 6th Grades Mathematics Lesson: Geometry Learning Field. Unpublished Master's Thesis, Gazi University, Ankara.

Mcmillan, J.H. and Schumacher, S. (2006). Research in Education: Evidence- Based Inquiry. Sixth Edition. Allyn And Bacon, $517 \mathrm{P}$, Boston, Ma.

Morrow, K. (1994). Effects of Cooperative Learning Groups Versus Whole Class Instruction on Achievement Scores In High School Geometry Classrooms. A Thesis Submitted to The School of Graduate Studies in Partial Fulfillment of The Requirement for The Degree of Master of Science. Southern Connection State University.

Nakiboglu, C. (2001). The Teaching of "The Nature of Matter" to Chemistry Prospective Teachers by Using Cooperative Learning: Effect on Achievement of Student. Gazi University Faculty of Education Journal. 21(3): 131- 143.

Ozcelik, D. A. (2010). Test Hazırlama Kılavuzu. (4. Baskı). Ankara: PegemA Yayıncılık.

Ozdogan, E. (2010), The Effects of Computer Aided Cooperative Learning on Geometric Skills of Elementary Fifth Grade Students. 9. Elementary Teacher Education Symposium, Elazığ.

Ozerdem, E. (2007). The Misconceptions on the Subject of Analytical Geometry and to Find Out a Solution in Licence Degree. Unpublished Master's Thesis, Dokuz Eylül University, Izmir.

Ozsarı, T. (2009). The Effect of Cooperative Learning Method to the Fourth Grade Students' Achievement on Mathematic Learning: Problem Based Learning (PBL) and Student Teams- Achievement Division Method (STAD). Unpublished Master's Thesis, Ege University, Izmir.

Ozyurt, D. A (2013). The Effect on Students' Academic Achievement of Cooperative Learning Model in Pratic of Science and Technology Course. Master's Thesis, Atatürk University, Erzurum.

Pınar, S. (2007). Effects of Learning "Measures" Topics on Students by Education Technologies and Cooperative Learning Methods. Master's Thesis, Marmara University, Istanbul.

Saritas, E. (2002). The Learning strategies, attitudes and performance levels of succesfull and unsuccesfull problem solvers in cooperative and traditional classes. Master's Thesis, Dokuz Eylul University, Izmir.

Savas, E., Obay, M. \& Duru, A. (2006). The Effect of Learning Activities on Students' Mathematics Achievement.Journal of Qafqaz University. 17(1). 
Slavin, R.E. (1991). Student Team Learning: A Practical Guide to Cooperative Learning (Third Edition). Washington D.C.: National Education Assocation Publication.

Tanel, R. (2006). Investigation of the effects of the cooperative learning method on understanding the second law of thermodynamics and Entropy. PhD Thesis, Dokuz Eylul University, Izmir.

Tarım, K. (2003). Effectiveness of cooperative learning method on teaching mathematics and meta analytic study for cooperative learning method. Unpublished PhD Thesis, Culurova University, Adana.

Tarım, K. and Akdeniz, F. (2008), The Effects of Cooperative Learning on Turkish Elementary Students' Mathematics Achievement and Attitude Towards Mathematics Using TAl and STAD Methods, Educational Studies in Mathematics, 67(1), 77-91

Timur, S. (2006). The effects of cooperative learning on student success in 7th grade primary education science course. Unpublished Master's Thesis, 18 Mart University, Canakkale.

Torun, O. (2009). The effect of the cooperative learning method supported by multiple intelligence theory on the seventh grade elementary schools in their mathematics subjects of geometrical shapes on their achievement and permanance. Master's Thesis, Gazi University, Ankara.

Tosun, C. and Taskesengil, Y. (2011), Development of an Achievement Test About Solutions and Their Physical Properties Based on Bloom's Revised Taxonomy: Validity and Reliability. Kastamonu Education Journal, 19 (2), (499-522).

Tsay, M. and Brady, M. (2010). A Case Study of Cooperative Learning and Communication Pedagogy: Does Working in Teams Make A Differance? Journal of the Scholarship of Teaching and Learning, 10 (2), 78 89.

Ural, A. (2007). The effect of cooperative learning on mathematics academic achievement, retention, mathematics self-efficacy and attitudes toward mathematics, PhD Thesis, Gazi University, Ankara.

Unlu, M. (2008).The Effect of Cooperative Learning Method on The Academic Success And Recall Levels of 8th Grade Students in 'Permutation and Probability' Subject. Master's Thesis, Gazi University, Ankara.

Unlu, M. and Aydıntan, S. (2011). The Views of $8^{\text {th }}$ Grade Students Related to Students Teams-Achievement Divisions Technique in Mathematics Education. Journal of Abant IzzetBaysal University Education Faculty, 11(1), 101-117.

Varank, I. and Kuzucuoglu, G. (2007). The Effect of Learning Together Technique of Cooperative Learning Method on Students' Mathematics Achievement and Cooperative Study Skills. Elementary Education Online (EEO), 6(3), 323-332.

Vaughan, W. (2002). Effects of Cooperative Learning on Achievement and Attitude Among Students of Color. The Journal of Educational Research,95(6), 359-364.

Yıldız, N. (2001). The Effect of Learning Method on Student Achievement in Mathematics Teaching of Primary School 7th Class. Master's Thesis, Balıkesir University, Balıkesir.

Zenginobuz, B. (2005 The Impact of Cooperative Learning Techniques on Student Academic Performance (Geometry), Master's Thesis, Marmara University, İstanbul. 